\title{
The Result of Data Technology on Employee's Performance in the Banking Sector at Karnataka - An Empirical Research with Supported Banks in Bangalore City
}

\author{
C.H. Raja Kamal
}

\begin{abstract}
In this study the researcher tries to understand the impact of new technology on employee's work efficiency in the banking sector. 10 bank's employees were concerned in Bangalore city and questionnaires contains 75 questions has issued to the employees. Initially researcher used descriptive type of analysis and later correlation analysis has used to get the findings. The banking area is a unit which is a victimisation of the information technology usage and application of information technology is a competitive tool that was attempted to as a new application to try and perform their regular banking activities with efficiency.
\end{abstract}

Keywords: Use of Technology in banking, Technology impact on banking, Information Technology effect on banking, Technology contribution to banking

\section{INTRODUCTION}

Information technology is playing an important role in all told trade. The banking industry encompasses the influence of financial services sector in Karnataka. Data technology which is a division of information technology was playing a prominent platform on that to spice up the country economical contentiousness. Generally it is a massive constructive impact on firms' productivity and it could increase the efficiency if the same is adopted and understood. It is a residue reliable that the influence of information technology on productivity of banking industry is more, with this analysis we can spot out the impact of Data technology on employees performance in banking industry. There are a unit of 10 bank's employees were concerned during this analysis, a questionnaire contains 75 questions was distributed to the bank employees who were working in both government and private bank sectors. Initially non-public banks have shown lot of curiosity to adopt information data technology in their banks and they have invested more to get well advance competitive advantage from government banking sectors.

Rezaei declared that, the importance of knowledge is a strategic plan of action in organizations is considered to be as a worth full resource that can be well in advance by different organizations. Basic knowledge on information will associate for nursing the assets of the organization to gain competitive advantage within the internal and external environmental setup of the organization. However numerous transformations may lead to the potential value and knowledge acquired through it may lead the organization to stand in its position by using the resources of the information technology organizations are able to gain the competitive adantage.

In recent days, researchers were concentrating more about how this information technology influencing the performance of the employees a much better and a broader insight to explore its impact has considered as a major issues for development of the organizations as well as employee performance. Sadiq, has taken a new look into it he says that with in the geographical point there is a greater impact on the human resource management. An H.R. manager uses information technology to urge, store and retrieve the information. With the information along we cannot get efficient work and it is not only the thing which is not going to improve the potentiality of the employee as well as organization however some additional operations are required to increase the efficiency of the operations. To desperate the different functions of the human resource management currently organizations are compatible with the human resource information system. Human resource information creeps to manage the employees and works those who are associated in an economical affair.

Employees of banking sector will have an additional interest to use the information technology because most of the banking activities are and every one bank activities reassess with the support of information technology either it may be done through using mobile banking, Money deposit Machine, net banking, ATM, cheque deposit machine SMS or E- Transformation. Most of the bank employees are expecting to do paperless operations in and the surrounding of the bank.

\section{REVIEW OF LITERATURE}

In Indian financial system the banking industry was affiliated with several different forces and the same banking sector was considered to be as a backbone of the Indian financial system. For the functioning of the banking sector in today's world the support of information technology is very 
much essential. In Indian economy the information technology and communication technology enlarged the banking sector. For nursing the economical industry, technology encompasses a major role. From the last one decade, banking sector in Asian nation has equipped heavily within the new technologies like credit cards, tele banking, debit cards, web banking, ATMs, mobile banking, electronic payments and reposition of information, data by processing into solution is leading to the enhancement in the quality that client expecting and also it is leading to the quick process. So many banks now a days making significant investments in information technology that leads to the improvements in the performance.

If banks want to provide high quality services to their customers in a secured manner banking sector needs to use the information technology and communication technology systems through which bank can provide reliable and sustainable secured services to their customers in a reasonable way then the banks in sight the competitive advantage that leads to the economic growth of the banking sector.

Banking industry plays a vital role in the development of Indian economy. Technology usage has given rise to productivity potency and penetration of the banking sector. Mobile banking area, electronic delivery channels, net primarily based banking, type of cards, and ATM's are the few outcomes of introducing the information technology in the banking sector are new outcomes of cybernation and automation in Indian Banking industry. By implementation of communication technology and information technology the banking sector has increased its effectiveness and creating the value for the transactions with viability.

\section{Mutation of Indian Banking Sector:-}

Over the last decade a complete transformation has seen in the Indian banking systems. Setting up the technological leads the sector to move seamlessly from a manual to a technological leading, this has been treated as an outstanding effect of the banking sector. This transformation doesn't taken place in a very long period of time it happened in just span of time with such a desultory price.

The entry of technology in Indian industry has taken place in nineties only and it may be attain all rounds in the Nineties and the banking sector is witnessed as a score of amelioration. The important objective of banking sector in India is to reform is self-direction, competition and flexibility with the system and it need to raise the standards of Indian banking system to International best practices. With the advantage of permitting standards, new close to home and outside banks rose furnished with most recent innovation. Discharge has opened new chances to banks to broaden incomes by enhancing into venture banking, protection, charge cards, contract money, office administrations and so forth. The job of banking is reclassified from an insignificant treater to support provider of grouped cash benefits underneath one rooftop acting kind of a cash nourishment showcase.

Knowledge of technology leading to the following presentations in banking sector:-

Presentation of MICR basically based check process
Landing of card essentially based instalments

Presentation of Electronic Clearing Services

Presentation of RTGS/NEFT

Presentation of Check Truncation System

Presentation of Core Banking Solutions (CBS)

Presentation of money container Machine (ATMs)

Presentation of Phone and Tele Banking

Presentation of net and Mobile Banking

\section{Trends in Indian banking inclination:-}

Base on the demand of customer the banking industry speedy amount of amendment of implementation of information technology to satisfy customer and sustain in the competition. The performance of the banks is mainly depends on the technology that banks are using and banks to get explore the innovation of product not only enough conjointly technology also need to be implemented.

In present scenario technology is not only dynamic it is also need to be setup conjointly with the customers. Technology brings the client relationship into a larger extent. It is going to act as associate as well as nursing tool to reduce the price and used to maintain effective relations with the customer which are main cause for the development of the banking business. The new services and merchandise can be opened through the usage of technology with different economical delivery channels of sector. Information technology provides the blueprint for industry to overcome the challenges facing by the industry and it is considered as the gift in setting the competitive spirit. Information technology allows chopping the value fund transfer in world wide.

Information Technology devices used by the banks in recent scenario:-

Cheques are the common instruments or units that are used in banking industry for receipts and payments. Cheques are well utilized in the place of money. Due to growing of banking dealing with automating clearing method instruments came into existence some of them are.

MICR, CTS, ECS, EFT, RTGS, CBS, ATM, Mobile Banking, Tele Banking, Development of Distribution Channels, Phone Banking, Internet Banking

Due to usage of all these types of instruments their banking sectors have restricted the limit of transactions. Usage mobile banking provides the information about the account balances and total number of transactions between the customer and other accounts has taken place. Customer can do the bill payments and fund transformations through electronic fund transfer system from one account to another account. So many applications came into existence like Phone Pay, Google Pay, Paytm, Bhim UPI which makes the customer to transfer the funds and bill payment easily.

\section{RESEARCH METHODOLOGY}

Different bank employee of Bangalore city has contacted to do the research was. Public and private banking sector employees have involved in this survey. Data has collected 
by issuing 75 questionnaires and results drawn in the proper manner with appropriate analytical tools.

\section{Objectives}

- To find out the scale of information technology adoption by the employee's in employment.

- To seek whether the employees are motivated with the usage of IT tools.

- To identify the error rate of the employees after adaption of IT.

- To enlighten the potency of employees by usage of IT.

- To find out employee satisfaction in using IT.

- To identify the increase in skill of employees by the usage of IT.

\section{Scope of the Study:}

In this study an attempt has been made to analysing the impact of technology adoption in selected banks employees of Bangalore city.

\section{Sources of Data Collection}

Primary data: The first hand information has collected through issuing a structured questionnaire to the selected bank employees of Bangalore metropolis urban.

Secondary data was collected from various journals, books, reports of run, analysis papers, online sources, related to the Indian Banks' and analysis in Banking Technology.

Hypothesis of the Study H01: There's an association between adoption of Technology and performance employee's.

Sample Design: Simple Random Sampling method is and the sample size was taken as 75 .

Statistical Tools and Techniques: Correlation and distribution, SPSS software system has used to do analysis and interpret the data.

\section{ANALYSIS AND INTERPRETATION RESULTS}

Testing of H01: There's an association between adoption of Technology and performance employee's.

Table - 1

\begin{tabular}{|c|c|c|c|c|c|c|}
\hline \multicolumn{7}{|c|}{ Correlation } \\
\hline Description & Correlation & $\begin{array}{l}\text { Internet } \\
\text { Banking } \\
\text { related } \\
\text { services }\end{array}$ & $\begin{array}{l}\text { Mobile } \\
\text { Banking } \\
\text { related } \\
\text { services }\end{array}$ & $\begin{array}{l}\text { Core } \\
\text { Banking } \\
\text { related } \\
\text { services }\end{array}$ & $\begin{array}{l}\text { Plastic } \\
\text { Money } \\
\text { related } \\
\text { services }\end{array}$ & $\begin{array}{l}\text { ATM } \\
\text { services } \\
\text { related } \\
\text { services }\end{array}$ \\
\hline \multirow{3}{*}{$\begin{array}{l}\text { Internet } \\
\text { Banking }\end{array}$} & Pearson Correlation & 1 & .797 & 931 & .869 & .897 \\
\hline & Sig. (two-tailed) & & .000 & .000 & .000 & .000 \\
\hline & $\mathrm{N}$ & 75 & 75 & 75 & 75 & 75 \\
\hline \multirow{3}{*}{$\begin{array}{l}\text { Mobile } \\
\text { Banking }\end{array}$} & Pearson Correlation & .878 & 1 & .903 & .957 & .632 \\
\hline & Sig. (two-tailed) & .000 & & .000 & .000 & .000 \\
\hline & $\mathrm{N}$ & 75 & 75 & 75 & 75 & 75 \\
\hline \multirow{3}{*}{$\begin{array}{l}\text { Core } \\
\text { Banking } \\
\text { Services }\end{array}$} & Pearson Correlation & .921 & .903 & 1 & .960 & .841 \\
\hline & Sig. (two-tailed) & .000 & .000 & & .000 & .000 \\
\hline & $\mathrm{N}$ & 75 & 75 & 75 & 75 & 75 \\
\hline \multirow{3}{*}{$\begin{array}{l}\text { Plastic } \\
\text { Money } \\
\text { Services }\end{array}$} & Pearson Correlation & .872 & .957 & .960 & 1 & .760 \\
\hline & Sig. (two-tailed) & .000 & .000 & .000 & & .000 \\
\hline & $\mathrm{N}$ & 75 & 75 & 75 & 75 & 75 \\
\hline \multirow{3}{*}{$\begin{array}{l}\text { ATM } \\
\text { services }\end{array}$} & Pearson Correlation & 879 & .632 & .841 & .760 & 1 \\
\hline & Sig. (two-tailed) & .000 & .000 & .000 & .000 & \\
\hline & $\mathrm{N}$ & 75 & 75 & 75 & 75 & 75 \\
\hline
\end{tabular}

Pearson correlation arrange from -1 to +1 to represent the correlation in this the negative numbers representing the negative correlation and positive numbers representing positive correlation. Whichever the value is closer to the value -1 or +1 represents stronger association is their between the variables. It was hypothesized a positive relationship between the Information Technology adoption and employee performance. Since the Pearson and correlation value was $(0.921)$ for the investor, $(0.879)$ for the bank services, $(0.878)$ for types of banking services, , (0.872) for Information Technology adoption and employee performance and it is significant, are supporting our hypothesis.

\section{Work Load of Employees}

Graph - 1

\section{Work load relief}

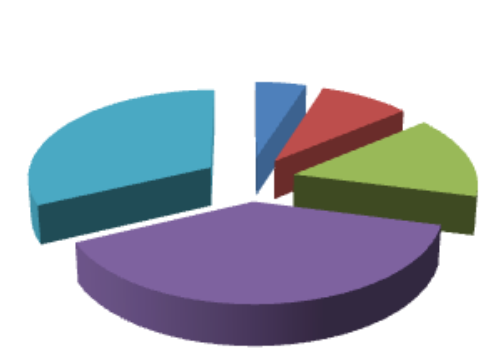

- Strongly Disagree

Disagree

neither agree nor disagree

agree
Strongly agree

Banking activities have enlarged in globally therefore the group action has extended across the planet. The objective of applications of information technology is to reduce the employee's work lord. The chart representing most of the employees agree that information technology reduces their work lord. This reduction in work load permits them to figure freely to step them with higher even in the graph $39 \%$ of employees agree, $32 \%$ of employees strongly agree that information technology reduces their work load.

Employees Satisfaction

Graph - 2

\section{Employee Satisfaction}

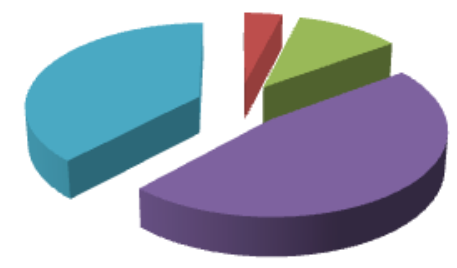

Strongly
Disagree
Disagree
neither agree
nor disagree
agree

- Strongly agree

The graph represents the employees satisfaction level, $47 \%$ of staff agree, $38 \%$ of employees strongly agree, $11 \%$ of employees neither agree nor disagree and $4 \%$ of the employees disagree towards their satisfaction level is high after implementing information technology which may lead to automatic generation of report and balance updates gives them higher level of satisfaction. 

KARNATAKA - AN EMPIRICAL RESEARCH WITH SUPPORTED BANKS IN BANGALORE CITY

Workers Skills

Table -2

\begin{tabular}{|l|c|c|c|}
\hline \multicolumn{1}{|c|}{ Opinion } & Frequency & Percentage & Cumulative percentage \\
\hline Strongly disagree & 5 & 6 & 6 \\
\hline Disagree & 9 & 12 & 18 \\
\hline Neither agreenor disagree & 11 & 15 & 33 \\
\hline Agree & 32 & 43 & 76 \\
\hline Strongly Agree & 18 & 24 & 100 \\
\hline & 75 & 100 & \\
\hline
\end{tabular}

The table shows the opinion of workers skills towards IT will increase the abilities of employees. 32 employees agree, 18 employees strongly agree, and 11 neutral during this, around 9 of them disagree and 5 of them strongly disagree, that As a result of it drives them to go for new technology.

Absence of workers

Table -3

\begin{tabular}{|l|c|c|c|}
\hline \multicolumn{1}{|c|}{ Opinion } & Frequency & Percentage & Cumulative percentage \\
\hline Strongly disagree & 3 & 6 & 6 \\
\hline Disagree & 6 & 12 & 18 \\
\hline Neither agree nor disagree & 4 & 15 & 33 \\
\hline Agree & 48 & 43 & 76 \\
\hline Strongly Agree & 14 & 24 & 100 \\
\hline \multicolumn{1}{r|r|}{ Total } & 75 & 100 & \\
\hline
\end{tabular}

The table shows the opinions of employees towards the absence of employees in banking sectors. 48 employees agree that the knowledge technology has reduced the absence of the staff 14 employees strongly agree due to the adoption of I.T tools makes their work easier than manual work.

\section{Workers Error rate}

Table -4

\begin{tabular}{|c|c|c|c|}
\hline Opinion & Frequency & Percentage & Cumulative percentage \\
\hline Strongly disagree & 2 & 6 & 6 \\
\hline Disagree & 17 & 12 & 18 \\
\hline Neither agree nor disagree & 22 & 15 & 33 \\
\hline Agree & 28 & 43 & 76 \\
\hline Strongly Agree & 6 & 24 & 100 \\
\hline Total & 75 & 100 & \\
\hline
\end{tabular}

Almost 28 employees agree that error rates have decreased by the implementation of IT application in their work place, at present banks are mistreating different package to do their transaction by this the error will detect mechanically therein.

\section{FINDINGS}

The present study completely focused on The Result of Data Technology on Employee's Performance in the Banking Sector in the Bangalore region with the help of collected data is presented here.

\section{Socio Economic Profile of Respondents}

- $52 \%$ are female employees and $48 \%$ are male employees.

- $20 \%$ of the bank employees have their monthly income in between the $12,000-20,000$ and $59 \%$ are between the $20,000-50,000$ and $21 \%$ of them in between 50,000 to $1,00,000$.

- $82 \%$ of the employees are graduates and $18 \%$ are qualified SSLC.

- $28 \%$ of the employees were in between the age group of $20-30$ and $22 \%$ of the employees are in between $30-40$ and $50 \%$ are 40 and above.

\section{Other Aspects}

According to the survey there is an high impact of technology on knowledge employee's performance. Introduction of technology in several systems of banking sector at all their operational activities made the method banking system got advantage. Even employees are happy due to reduction in their work load which is leading to increase the talents and skills of the employees by providing coaching and it also provides the chance to access with world market.

\section{LIMITATIONS OF THE STUDY}

The current study has few limitations as follows:

- This paper examines only the impact of information technology adoption on Employees performance level.

- The scope of the research covered on Bangalore urban area

- The study is based on information obtained through primary and secondary data.

- This study is confined with seventy five sample size.

\section{CONCLUSION}

The study examined The Result of Data Technology on Employee's Performance in the Banking Sector at Karnataka - An Empirical Study with supported Banks in Bangalore city. The analysis shows that there is an impact on employee's performance. The performance has measured in some ways like enhancing the skills and satisfaction, decrease in work lord, acting as a motivation tool, scale back the absence of employees. The study ends with saying that information technology correlates with the performance of employees. The results also show that, application of information technology scale backs the absence of employees and also reducing the error rate.

\section{REFERENCES}

1. Mirriam N., Effect of Information Technology on Employee Productivity in Selected Banks in Kenya, a Review of Contemporary Business Research, Vol. 4, No. 1, pp. 49-57, June 2015.

2. Maryam Rezaei, Majid Zare, The Effects of Information Technology (IT) on Employee

3. Shahr Bank Management and Technology pp. 1208-1214, Sep. 2014.

4. Meisam Latifi. The impact of information technology on firm performance; a focus on employee profit chain, IJMS, pp. 95-120, Jan 2014.

5. Bahaudin G. Mujtaba, The Impact of Information Systems on the Performance of HumanResources Department, Journal of Business Studies, pp. 77-91, 2012.

6. Paritosh Kumar, Impact of Information Technology in Indian Banking Industry. 